\title{
Model for Tutoring in Reading and Writing Tasks for Brazilian Children with Developmental Dyslexia
}

\author{
Andréa Carla Machado*1, Simone Aparecida Capellini ${ }^{2}$ \\ ${ }^{1}$ Child Research and Development Center- CRDC. Sao Jose do Rio Preto, Sao Paulo State, Brazil. \\ ${ }^{2}$ São Paulo State University "Júlio de mesquita Filho - UNESP. Marilia, Sao Paulo State, Brazil.
}

* Corresponding Author: Andréa Carla Machado, Child Research and Development Center- CRDC. Sao Jose do Rio Preto, Sao Paulo State, Brazil. E-mail: decamachado@gmail.com

Received date: September 09, 2019; Accepted date: October 12, 2019; Published date: October 16, 2019

Citation: Machado C. A., Capellini A. C. (2019 Model for Tutoring in Reading and Writing Tasks for Brazilian Children with Developmental Dyslexia J. Neuroscience and Neurological Surgery. 5(1); Doi: 10.31579/2578-8868 /092

Copyright: ( 2019 Andréa Carla Machado. This is an open-access article distributed under the terms of The Creative Commons Attribution License, which permits unrestricted use, distribution, and reproduction in any medium, provided the original author and source are credited.

\begin{abstract}
Developmental dyslexia is characterized by impairment in reading and writing because of changes in the cognitive-linguistic behavior and anatomic functional structures. The goal of the research was to analyze and compare the performance on the skills of reading and writing in children with developmental dyslexia after a tutoring program. Participated of the study fifteen children from both genders from the 2 rd to the 6 th year from public schools in a city in the State of São Paulo. They were divided into two groups: GI-experimental and GII - control group. Were divided according to sex and age group. The children were subjected to the assessment of reading and writing and to the intervention program in Reading Recovery tutoring. The results revealed statistically significant difference between the GI and GII, where children with dyslexia in the GI showed superior performance on the skill of reading words and reading the book I in relation to children from the GII. It was concluded that the GI introduced significant advances compared to GII that did not receive tutoring intervention, demonstrating that due to variability of cognitive-linguistic profile of children with dyslexia, it is necessary to develop, mainly, in the school context, multi method programs with specific difficulties that focus on interventions of this population.
\end{abstract}

Keywords: dyslexia; children; reading; writing. tutoring

\section{Introduction}

Developmental Dyslexia is characterized by impairment on reading simple words often involving cognitive-linguistic deficits, also pointing to changes in motor and visuospatial skills, affecting individuals without sensorial disabilities, free of significant and emotional commitment with appropriate educational opportunities [1] [2]. The Dyslexia (DD) hereditary temporal processing defect, associated with impaired magnocellular neuronal development,that impacts selectively on the ability to learn to read, leaving oral and non-verbal reasoning powers intact [3].

In this perspective, the study [4] [5] [6] indicates that there is a variability in cognitive-linguistic profile of dyslexic, maximizing the importance to develop intervention programs consistent with such losses, especially those who are reading and writing tasks in the same context. For example, whereas the flaws in the writing of the dyslexic children comprise mostly linguistic structures similar to those found in typical development children, they are persistent, popping up with more frequency and prevalence [7].

The reflexes of orthographic difficulties, for example, experienced by the dyslexic

children tend to be more extensive than in reading, since, in addition to cognitive requirement imposed by his own writing, the Portuguese language is less transparent for writing than for reading [8].

With children identified as at risk, based on this selection, an additional short-term intervention. This intervention can evolve from Auctores Publishing-Volume 5(1)-092 www.auctoresonline.org Page-1 small groups for individual classes based on the needs of the child. Monitoring progress is used to measure the response of children for intervention. Those who do not respond to additional intervention are considered to be at risk for dyslexia and can benefit from a more specialized education provided within a context of special education [9].

That said, there is a wide range of investigations into mode and instructional

procedures [26] [10] provided outside the regular classroom to assist Children who have difficulty in early reading and writing skills. Mentoring is a mode in which the tutor offers a single follow-up to the student seeking to improve results. Mentoring-based interventions contribute to the development of reading and writing skills of the child, and it is a facilitator for the performance via context of the classroom. In other words, the intensive intervention in the form of tutoring is held individually in the educational area, in which the tutor helps students to overcome their difficulties, becoming an important mediator element for effective pedagogical interaction and academic performance [11]; [12]

The findings [13] consistently across methods, demonstrate a causal role of the Magnocellular Dorsal - MD, pathway deficit in DD. This comprehensive multimethod approach provides important evidence to the long-lasting debate about the MD theory.The authors suggest that the unsuccessful search for a single cause for DD makes the identification of other causes than phonological awareness of utmost importance to the development of more efficient remediation and 


\section{J Neuroscience and Neurological Surgery}

prevention programs. The fact that the MD deficits can be tested in pre-readers (even at the infant level) paves the way for more effective DD remediation and prevention programs.

In this way, children with developmental dyslexia diagnosis can be study aimed to analyze and compare the performance on tasks of reading and writing in children with developmental dyslexia after a mentoring program based on the model of RTI [14].

\section{Method}

This study was conducted after approval from the Research Ethics benefited with the opportunity to participate in interventions that aim to offer activities focused on instructional tutoring. Based on the above, this

Committee from the Philosophy and Sciences College from Sao Paulo State University "Julio de Mesquita Filho"- UNESP- Marilia, Sao Paulo State, Brazil, under Protocol Number 1589/2008. The present study is characterized as an experimental study conducted with children from the public school in the city of Marilia-SP, who met at the Center for the Study of Education and Health CSEH/UNESP.

\begin{tabular}{|l|c|c|}
\hline & Treatment (GI) & Control (GII) \\
\hline Age in years mean \pm SD & & \\
Grade \% & $9.4 \pm 1.8$ & $9.2 \pm 1,3$ \\
Grade 2 & & 10 \\
Grade 3 & 16 & 20 \\
Grade 4 & 25 & 50 \\
Grade 5 & 44 & 10 \\
Grade 6 & 8 & 10 \\
Male \% & 7 & 100 \\
Female \% & 75 & 0 \\
& 15 & \\
\hline
\end{tabular}

Table 1. Characteristics of the Cohort. Fifteen children.

The group were divided into:- Group I (GI): composed of 7 children with the diagnosis of interdisciplinar developmental dyslexia, who received tutoring, met at the Center for the Study of Education and Health - CSEH/UNESP; and,

-Group II (GII): composed of 8 children with the diagnosis of interdisciplinar

Development dyslexia met in the Center for the Study of Education and Health - CSEH/UNESP, which did not receive tutoring.

The requirements for the inclusion criteria were: children without eyesight and hearing and cognitive performance within the standards of normality described in handbooks from the EWCS; children at risk for developmental dyslexia proven by CSEH assessment; never having participated in intervention programs, educational or neuropsychological speech therapy.

The requirements for the exclusion criteria were: children with eyesight and hearing and cognitive performance below the standards of normality described in charts; genetic syndromes or other syndromes; Hearing impairment; Visual impairment; Mental Deficiency.

For the realization of this study the following procedures were used:

a-) post Informed Consent form: As Brazilian National Health Council resolution 196/96 BNHC, prior to the start of assessments, the selected parents or guardians of patients signed the post Informed consent form for authorization of completion of study. b-) diagnostic survey of reading and writing (pre and post-test): This instrument was applied individually in children both the experimental group-GI, as well as on children belonging to the control group-GII, lasting one hour each application. The instrument that evaluated the performance of children in six tasks: the skill of writing concepts (1) is to ask to identify sixteen concepts (the cover of the book, where it is read, where one starts to read, to which direction to go, the meaning of punctuation marks, among others). In the skill of free words writing (2), the child is asked to write as many words that are found in a blank sheet during the period of five minutes and then read them. In the task of writing the dictated words (3), the child was asked to write four words (one syllable - rã (frog), a two syllable - carro (car), a three syllable - brinquedo (toy) and a polysyllable chocolate (chocolate), chosen from a list of previous words) and two simple sentences "Pitoco come bolo" (Pitoco eat cake) and "Ele bebe leite" (He drinks milk). In the task of identification letters (4) the child was asked to recognize uppercase and lowercase letters of the alphabet and point a word with each letter.

In the task of Reading (5), it was requested that the child read a list composed of 14 simple and complex words. In the task of reading books (6), the first book was illustrated ("A Foca Famosa" (the Famous Seal) by Sonia Junqueira - Estrelinha series) containing 111 compound words of simple and easy syllables to understand and the second book (was taken from Cartilha Pipoca, by Paul Abdullah) containing 106 words composed of simple and complex syllables, the absence of images and more complex sentences, in addition to the implicit outcome. c-) mentoring program: it was performed at the laboratory of learning Deviations (read) the Centre for the study of education and health - CSEH/UNESP in Marilia, Sao Paulo Satate, Brazil in eighteen individual sessions lasting an hour each with weekly frequency. Thus, the program followed the following steps:

1-) re-reading made by student or read along with the researcher/tutor of a book already read in the previous session; 2-) retelling the story told earlier and identifying the letters made by the student through playful activities with focus on letter-sound relationship (movable alphabet letters, written on paper, magnetic Whiteboard); 3-) oral and written separation of words into syllables for the child to look at the sounds; 4-) writing of sentences by the student, from the retelling and assembling the same story of the book (storyline); -5) separation of sentences into words, words into syllables (storyline); 6-) introduction of a new book and reading, with the help of researcher/tutor of this book. It should be noted that both the diagnostic Survey, as well as the mentoring program used in this research was based on Reading Recovery Program proposed by Mary Clay [15]

The results were analyzed statistically, using the Wilcoxon test and Kruskal-Wallis test, due to sample size of individuals, to check possible performance differences in the tasks between the study groups and variance analysis, and the significance level adopted was of $5 \%(\mathrm{p}=$ 0.050 *). For data analysis program was used SPSS (Statistical Package for Social Sciences), in its version 13.0. 


\section{Results and Discussion}

In table 2, it can check the average, standard deviation and the writing tasks. The results revealed significant differences for the reading of words and reading the book 1 , in children with dyslexia who participated in interventions.

\begin{tabular}{|c|c|c|c|c|c|c|}
\hline & N & Average & $\begin{array}{c}\text { Stamdard } \\
\text { Deviation }\end{array}$ & Min & Max & Sigf. (p) \\
\hline EC (PRE) & 7 & 76.20 & 18.52 & 37 & 100 & 0.929 \\
\hline EC (POS) & 7 & 75.13 & 13.84 & 56 & 100 & \\
\hline FW (PRE) & 7 & 64.73 & 23.53 & 16 & 94 & 0.201 \\
\hline FW (POS) & 7 & 7267 & 20.91 & 40 & 100 & \\
\hline ED (PRE) & 7 & 75.13 & 22.53 & 19 & 100 & $00.56^{*}$ \\
\hline ED (POS) & 7 & 82.67 & 18.39 & 34 & 100 & \\
\hline LI (PRE) & 7 & 86.00 & 15.44 & 42 & 100 & 0.344 \\
\hline LI (POS) & 7 & 88.67 & 10.15 & 70 & 100 & \\
\hline RW (PRE) & 7 & 71.47 & 26.17 & 21 & 100 & $0.012^{*}$ \\
\hline RW (POS) & 7 & 79.20 & 26.23 & 21 & 100 & \\
\hline RB1 (PRE) & 7 & 75.53 & 28.59 & 00 & 100 & $0.020^{*}$ \\
\hline RB1 (POS) & 7 & 84.20 & 17.43 & 43 & 100 & \\
\hline RB2 (PRE) & 7 & 70.33 & 33.52 & 00 & 100 & 0.451 \\
\hline RB2 (POS) & 7 & 76.53 & 22.11 & 40 & 100 & \\
\hline
\end{tabular}

Legend: EC-concept of writing; FW- Free Writing; ED-written under dictation; LI-Letter Identification; RW-Reading of words; Reading Book 1; LL2- Reading Book 2.

Table 2. Average, standard deviation, and median, "p" value for the performance of children of GI for scores in reading and writing tasks.

Table 3 presents the average, the standard deviation and the "p" value for the Group 2 (GII) for the score from reading and writing tasks. The findings showed no statistically significant differences in any task of reading and writing proposed by mentoring program, i.e. children of GII that did not receive intervention, not advanced in the tasks.

\begin{tabular}{|l|l|l|l|l|l|l|}
\hline $\begin{array}{l}\text { Pair of } \\
\text { Variables }\end{array}$ & N & Average & $\begin{array}{l}\text { Stamdard } \\
\text { Deviation }\end{array}$ & Min & Max & $\begin{array}{l}\text { Sigf. } \\
(\mathrm{p})\end{array}$ \\
\hline & & & & & & \\
\hline EC (PRE) & 8 & 83.00 & 6.93 & 75 & 87 & 1.000 \\
\hline EC (POS) & 8 & 83.00 & 4.36 & 80 & 81 & \\
\hline FW (PRE) & 8 & 59.67 & 26.69 & 35 & 56 & 1.000 \\
\hline FW (POS) & 8 & 58.33 & 16.07 & 40 & 65 & \\
\hline ED (PRE) & 8 & 67.00 & 21.38 & 50 & 60 & 0.285 \\
\hline ED (POS) & 8 & 88.33 & 2.89 & 85 & 90 & \\
\hline LI (PRE) & 8 & 90.00 & 2.00 & 88 & 90 & 0.317 \\
\hline LI (POS) & 8 & 92.67 & 6.43 & 88 & 90 & \\
\hline RW (PRE) & 8 & 77.00 & 5.57 & 71 & 78 & 0.109 \\
\hline RW (POS) & 8 & 84.00 & 8.54 & 75 & 85 & \\
\hline RB1 (PRE) & 8 & 89.00 & 3.46 & 87 & 87 & 1.000 \\
\hline RB1 (POS) & 8 & 88.33 & 0.58 & 88 & 88 & \\
\hline RB2 (PRE) & 8 & 79.67 & 6.11 & 73 & 81 & 0.285 \\
\hline RB2 (POS) & 8 & 83.00 & 5.20 & 80 & 80 & \\
\hline
\end{tabular}

Legend: EC-concept of writing; FW- Free Writing; ED-written under dictation; LI-Letter Identification; RW-Reading of words; Reading Book 1; LL2- Reading Book 2. 


\section{J Neuroscience and Neurological Surgery}

Table 3. Average, standard deviation, and median, "p" value for the performance of the children of the GII for scores in reading and writing tasks.

In this study, the situations were compared pre-and post-scores in children with developmental dyslexia, in which the GI Group received intervention with reading and writing tasks with mentoring and GII did not receive the intervention program. Having a breakout performance against the tasks analyzed in the GI group. In this way the losses presented by children with dyslexia leads to the understanding that these children have learning disabilities, and are in need of educational activities targeted to assist in school performance.

In regards to the concept of writing tasks and letter identification it was found that the children of the GII showed no significant differences compared to the GI. However, the elements of these variables, such as letter recognition, directional movement of writing, and knowledge of the sounds of the letters should be worked on anyway, because children with dyslexia have losses in the process of literacy, where these elements are fundamental for good academic performance in the context of the classroom [16].

In the free writing tasks and written under dictation, it was also not observed diferences between the groups involved in the study, at posttesting. However, these results can be explained due to words used for these tasks which belong to the category of regular words, i.e. words that have letters in its structure with unique sounds, a sound for each letter, without present ambiguity.

The results found in this study will meet the studies that indicate the interlinguistic factor [17] 16,18] as responsible for the differences found in surveys conducted in some languages - differences in regularity or transparency of spelling, because it is known that there are differences in the ease in which children acquire the skills of fitness among the languages. Thus, dyslexic children who speak Portuguese (a transparent language) achieve success in using some alphabetical skills with regular words, as found in this study, for example.

The studies in this aspect [19] remind us that, although the main sign of dyslexia is often a problem of reading, the deficit in the writing is more properly considered as one of several possible behavioral manifestations of an underlying cognitive deficit. Therefore, the professional involved in the child's schooling process must also pay attention to the acquisition, as this spelling ability needs to be crafted so that future losses are mitigated.

The findings of this study point out that the tasks of reading words and reading books, are related to phonological awareness skills, attention and short-term memory ability. However, even though we cannot state in this study the direct relationship of such functions, we can consider that these functions mentioned above can influence on academic performance. So stressing that specific interventions directed to the area of injury of children with dyslexia support to assist effectively the teaching of reading and writing [20] [19].

In another qualitative analysis in the tasks of writing concept, writing

\section{References}

1. Snowling MJ, Stackhouse J. (2004). Dislexia, fala e linguagem: um manual do profissional. Porto Alegre: Artmed.

2. Fusco N, Okuda PM, Capellini SA. (2011). Avaliação e intervenção com a habilidade visomotora em escolares com dislexia e distúrbio de aprendizagem. In: Capellini SA, Silva C, Pinheiro FH. Tópicos em transtornos de aprendizagem. São José dos Campos: Pulso Editorial.

3. John Stein. What is Developmental Dyslexia? (2018). Brain Sci. Feb; 8(2): 26.

4. Valdois S, Bosse ML, Tainturier MJ. (2004). The cognitive deficits responsible for developmental dyslexia: Review of evidence for a selective visual attentional disorder. Dyslexia, 10(4): 339-363. of single words and dictated writing, the assessed children presented different results within the same condition, because it is considered, according to) $[4,5]$ the different manifestations in the cognitivelinguistic profile of Dyslexic.

Thus, the findings of the study point to individual differences children with dyslexia compensatory, because it is known that in the absence of the phonological code types - its deficit, other compensation strategies are developed [22] [23]

These results will meet their studies [24] that indicate the interlinguistic factors as responsible for the differences found in surveys conducted in some languages - differences in regularity or transparency during spelling. To some extent, the didactic approaches reflect the nature of the task to be learned, and there are growing evidence that the demands of learning of reading and writing differ between languages, Portuguese (considered a transparent language) and English (opaque language), for example. However, today it is known that there are differences in the ease in which children acquire the skills of shaping among the languages.

Thus, Dyslexic readers who speak Portuguese (a transparent language) achieve success in using some alphabetical skills with regular words, as found in this study, for example.

\section{Conclusion}

From the results of this study, it was concluded that there was a significant improvement in some reading and writing tasks when these were administered in an intervention program with tutoring. With proposal for advancing the process of reading and writing of a child with dyslexia, such a model also features an effectivity in relation to reducing false-positive cases in relation to the disorder, thus offering a wholesome way to help children with dyslexia in the schooling process. This study thus shows that Brazilian children with dyslexia improve their declarative knowledge, by internalizing reading as well as improve their procedural knowledge by applying this knowledge in word decoding. The change in word reading skills after the intervention, showing the approach to work for the group as a whole. From the aspects pointed out, we can consider that the results of this study have practical implications for prevention, mainly focusing on the tasks of reading and writing as important activities to assist in the preparation of interventions aimed at decreasing the failure of children who have developmental dyslexia. The literature indeed suggests that the school experience of children with developmental dyslexia, when enriched with activities conducive to the development of strategies can provide a substantial enhancement in the development of these skills.

5. Coltheart A, Castles A. (1993). M. Varieties of developmental dyslexia. Cognition. (47):149-180.

6. Germano GD, Pinheiro FH, Capellini SA. (2011). Subtipos da dislexia do desenvolvimento no portugues brasileiro: estudo preliminar. In: Ribeiro, A. A. (Org.)Temas em cognição linguagem e aprendizagem. Ubá.

7. Zorzi JL, Ciasca SM. (2008). Caracterização dos erros rtográficos em crianças com transtorno de aprendizagem. CEFAC. 10(3): 321-331.

8. Mousinho R, Correa J, Mesquita F. (2010). Perfil da escrita da criança disléxica. In:

9. Capovilla, F.C. Transtornos de aprendizagem: progressos em avaliação e intervenção

10. preventiva e remediativa. São Paulo: Memnon.

11. Machado AC, Almeida MM. (2012). A consultoria colaborativa e o modelo de resposta a intervenção (RTI) como propostas 


\section{J Neuroscience and Neurological Surgery}

inclusivas. In: Ribeiro, A. A. (Org.) Temas em cognição linguagem e aprendizagem. Ubá.

12. Vellutino FR, Scanlon DM. (2002). The interactive Strategies approach to reading intervention. Contemp. Edu. Psych. (27): 573-635.

13. Machado AC, Capellini SA. (2014). Tutoria em leitura e escrita baseado no modelo de RTI-resposta à intervenção em crianças com dislexia do desenvolvimento. Revista CEFAC, 16(4): 1161-1167.

14. Machado AC. (2009). Tutorial baseada na leitura de livros em escolares com dislexia do Desenvolvimento e distúrbio de aprendizagem. São Carlos [dissertação]. Educação Especial do indivíduo especial. Universidade Federal de São Carlos.

15. Gori S, Seitz A, Ronconi L, Franceschini S, Facoetti A. (2015). Multiple causal links between magnocellular-dorsal Pathway déficit and Developmental Dyslexia. Cerebral Cortex (26): 43356-4369.

16. Fletcher J, Btwbing KK, Barthv AE, Miciak J, Francis DJ, Denton CA. (2014). Agreement and Cowerage of indicators od Response to intervention: A multimethod comparison and simulation. Top Language Disorders. 34 (1): 74-89.

17. Clay MM. (1993). The early detection of reading difficulties. Portsmouth, NH: Heinemann.
18. Davies R, Cuetos F, Glez-Seijas R. (2007). Reading development and dyslexia in a transparent orthography: a survey of Spanish children. Ann. of Dyslexia. (57): 179-98.

19. Lyytinen H, Erskine J, Hamalainen J, Torppa M, Ronimus M. (2015).Curr Dev Disord Rep, 2:330-338

20. Capellini SA, Lanza S. (2010). Desempenho de escolares em consciência fonológica, nomeação rápida, leitura e escrita. PróFono. 22(3): 239-244.

21. Dias RS, Ávila CRB. (2008). Uso e conhecimento ortográfico no transtorno específico de leitura. Revista da Sociedade Brasileira de Fonoaudiologia. 13(4): 381- 190.

22. Olson, RK, Davidson BJ, Kliegel R, Davies SE. (1984). Development of phonetic memory in disabled and normal readers. Journal of Experimental Child Psychology. (37):187-206.

23. Rack JP. (1985). Ortographic and phonetic coding in normal and dyslexic reading. Bristish Journal of Psychology. (76): 325-340.

24. Cossu G. (1999). Biological constraints on literacy acquisition. Read and Writ. (11): 213-237.

25. Vicari S, A Finzi, D Menghini, L Marotta, S Baldi, and L Petrosini. (2005) Do children with developmental dyslexia have an implicit learning deficit? J Neurol Neurosurg Psychiatry. Oct; 76(10): 1392-1397.

26. Wanzek J, Vaughn S. (2008). Response to varying amounts of time in reading intervention for students with low response to intervention. Journal of Learning Disabilities, 41(2): 126-142. 